\title{
Islam and Modernity: The Case of Women Today
}

\author{
L. O. Abbas \\ University of Ibadan, Nigeria
}

\begin{abstract}
Islam places high premium on modernity, civilisation as well as impact of women towards the development of a society. The common slogan of women rights is not new in the Islamic system of administration as it is part and parcel of the tenets of Islam right from its inception. Earlier Muslim women played pivotal roles in different spheres of life, such as educational, economic, political and social advancement. These roles serve as models for women in this modern world. There are a number of accounts in Islamic history that express the roles played by women and that is why Islam is gender sensitive in all affairs of life as both man and woman form a society. This research therefore examines the status of women especially that of Muslims in this century and calls them to the challenges ahead of them towards the modernisation in Islamic perspective.
\end{abstract}

Keywords: Islam, modernity, civilization, women rights

\section{Introduction}

Family, society and ultimately the whole of mankind is treated by Islam on an ethical basis. Difference in sex is neither a credit nor a drawback for the sexes. The Qur'an 4:1 expresses the kind of treatment that Islam accords women.

Man and woman have, from the inception of human race, been made different genders mainly to raise their population and be partners to each other. Woman, is however, made to play a subordinate role of her man counterpart having been created for him. Each is given roles commensurate with his or her nature that fits his or her responsibilities. This phenomenon had for long been seen as a divine order and had been satisfactorily operated through ages. This beautiful separation of human duties has for so long been abused by the so-called stronger sex by subjugating the woman and treating her like slave. A clear example is that of the Jahiliyyah period, a period immediately before the advent of Islam. Islam normalises the order as put in place by the Creator and restores the dignity of woman and all her entitlements, rights and privileges. The scenario as described above was referred to by some sections of people at the time as modernity. Then came the so-called modern age when things that had been done in the past would be regarded as barbaric, archaic and sometimes old version.

\section{Concept of Modernity}

The word modern originates from the Latin word modernus, which defines the separation from pagan Rome with the acceptance of Christianity (Esposito, 2003). Today the term modern is used to highlight the meaning of new; different from the past. The word gained its meaning through the enlightenment, during which

L. O. Abbas, ph.D, Department of Arabic and Islamic Studies, University of Ibadan, Nigeria.

Correspondence concerning this article should be addressed to University of Ibadan, Nigeria. E-mail: latabs03@yahoo.com. 
rationality and ideas of liberty challenged the influence of religion over society. It is considered to be a process that originated from the thought of being modern (Aysu, 2006).

Modernity is a condition of being new and modern (Sally, 2001). It is also defined as a social dream which every human generation interprets to suit the reality of its own purpose. It is a term which keeps redefining itself from time to time in accordance with the reality of the moment. There has never been a time in the life of man when modernity was not proclaimed as expression of human advancement. Within the sphere of modernity, every age or generation has its own slogan. By and large, every slogan in vogue is considered modern and superior to the previous one. A major slogan of this age to which the current global youth seem to be addicted is "freedom". In the vanguard of what is called freedom is "woman rights" (Online Encyclopedia of Islam, 2013). This notion suggests that hitherto, women were in bondage. This controversial notion that started in the twilight of the $18^{\text {th }}$ century has engendered a new trend of restiveness across races, genders and religions in today's world.

The modernisation process was followed by the appearance of women in public life at the end of the $19^{\text {th }}$ and beginning of the $20^{\text {th }}$ century. The impact of the West, economic problems, educational reforms, and conditions after World War I made it easier for women to enter public life (Aysu, 2006). During World War I, women replaced men in some government offices, such as mail services. At the beginning of the $20^{\text {th }}$ century, half of the textile workers were women, and in 1897, half of the personnel in matchstick factories were women. Women from the lower classes were already working during the Ottoman Empire in the factories and homes. With the educational reforms, women's educational status improved, and they formed a new working class. Women in University education, secondary and vocational schools helped to employ women as teachers and nurses. Besides their participation in the labour force, women founded charity organisations and became socially active (Bullough, 2001 and Aysu, 2006). Modernity has largely been a process affecting Western civilisations. It begins with a change of thought in understanding daily practices. It is a paradigm that surrounds democracy in politics, capitalism in economy, positivism in science, and gives its name to the collection of all these (Alya, 1982). It starts with the enlightenment and symbolises separation from the past and requires a process that usually goes from traditional to modern. The main proposition behind the theories of modernity is that every society undergoes a process of transformation in phases and cannot be obstructed. Modernity is as well related to Westernisation of the world and consequently globalisation (Moghadam, 1992).

The demand for equal gender rights first came in a book authored by a woman, Mary Wolls entitled "An Indication of the Rights of Women", which was published in 1792. It began the campaign for the rights of women. With that book, the notion of equality of gender began in earnest and it quickly gained momentum in Europe and America. In a manner of authenticating the idea and in order to give women same treatment as men's in all spheres of life, regardless of what nature apportions for them, a British Orientalist, Edward William Lane introduced a religious dimension to it in his publication entitled "An Anthology of the Qur'an" in 1843. In his foreword to the book, he stated that "the fatal point of Islam is the degeneration of woman..." (Lane, 1843). For more than 150 years thereafter, Lane's misconception of degradation of Muslim women continued to gain ground and quoted by fellow Western Orientalists with reference.

\section{An Overview of Religious View on Gender Position}

The three main popular religious books viz, the Bible, the Torah and the Qur'an agree on some concepts and differ on others. For instance, on the issue of decision making or resolution, which is fundamental in 
human right, the Bible holds that a man must fulfil any vow he might make to God and must not break his word. On the other hand, it is stated that a woman's vow is not necessarily binding on her. It has to be approved by her father if single or husband if married (Rom. 30).

Among the Rabbis, the man is given powers to betroth his daughter whereas the woman is not given that right. Their unity indicates that marriage represents the transfer of control from the father to the husband through marriage. One main reason adduced for serious agitation for gender equality in the West was the Biblical attitude towards their social status. Western women had suffered for almost 200 years vis-a-vis their fathers and husbands.

In Islam, the vow of every Muslim, male or female is binding on him or her. No one has the power to repudiate the pledges of anyone else. Also in Islam, failure to keep a solemn oath made by a man or woman is extensively expressed. This includes:

God will only call you to account for your deliberate oaths, for expiation.

The companions of the prophet used to present their oath of allegiance to him personally. Women, as well as men, independently came to him to give their oaths. This is supported by Qur'an thus:

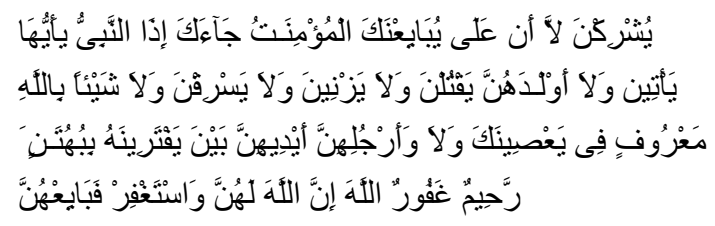

O Prophet! When the believing women come to you pledging to you, that they will not associate anything with Allah, and that they will not steal, and that they will not commit Zina, and that they will not kill their children, and that they will not utter slander, fabricating from between their hands and their feet, and that they will not disobey you in Ma'ruf (good), Allah said to the faithful believers, Verily, Allah is Oft-Forgiving, Most Merciful

\section{The Natural Principle of Balance}

The relationship between man and woman is naturally built on the principle of division of labour. Man's responsibility is to engage in tasks outside home, while the woman for tables inside home. Muhibuddin (1994), in his book Woman Between Islam and Western Society, states that

"The word qawwamun in the Qur'an is an indication of the wisdom of the division of labour rather than superiority of man over the woman. Naturally, a woman's responsibility in running the table is due to her passive nature, her tender gentleness and motherly affection all of which qualify her for domesticity".

\section{An Overview of the Status of Women in Islam}

Women's status in Islam is categorised into four aspects viz: spiritual, social, economic and political aspects. The Qur'an provides a clear-cut evidence that woman is completely equated with man in the sight of God in terms of her rights and responsibilities. The Qur'an states:

"Every soul will be (held) in pledge for its deeds" (Qur'an).

Socially, the right of females to seek for knowledge is not different from that of males (Abdullah, 1986). In consideration of the physiological and psychological make-ups of man and woman, both have equal rights and claims on one another, except for one responsibility, that of leadership. This is a matter which is natural in any collective life and is consistent with the nature of man. The Qur'an thus states: 
They (women) have rights similar to those (of men) over them, and men are a degree above them (Qur'an ).

Such degree is maintenance and protection. This refers to that natural difference between the sexes, which entitles the weaker sex to protection. It implies no superiority or advantage before the law. Yet, man's role of leadership in relation to his family does not mean the husband's dictatorship over his wife (Abdullah, 1986; Jamal, 1980). Economically, Islam provides a right for woman which was deprived her before Islam, the right of independent ownership. According to the Islamic Law, a woman's right to her money, real estate, or other properties is fully acknowledged. It is nowhere suggested in the Shari'ah that a woman is a minor simply because she is a female. With regard to woman's right of employment, it is the same with man counterpart and that is in addition to being a mother and a wife, which is sacred and essential (Abdullah, 1986).

In order to make women contribute to modernity, Islam recommends acquisition of knowledge as a required tool. The prophet of Islam even compelled seeking for knowledge for both male and female. Therefore, there is no restriction of female in acquisition of knowledge (Ahmed, 1992). The role of early Muslim women in scholarship cannot be over emphasised. They contributed particularly in the transmission of Ahadith (Traditions of the prophet) and in other areas of knowledge. For instance, A'ishah, the Prophet's wife, was a prolific transmitter of hadith as a significant number of her reports have been recorded. She was also renowned for her exegesis of the Qur'an and was consulted widely by the closest associates of the Prophet on account of her knowledge of the religious law (Boyd, 1989). During the later periods, people have evidence of impressive scholarship evinced by women as recorded in Islamic history.

Females also feature in the teaching profession. A great number of account is documented on their significant impacts on inculcation of knowledge to people; both males and females. The settings include the Madrasah (school), informal study circles (halqah) and private homes. Two of the most important madrasah are the Zahiriyyah and the Salihiyyah in Cairo, Egypt where some of these women received their education and they also later taught (online encyclopedia of Islam, 2013). Clearly, these women were empowered by their specific social and familiar circumstances which appear not to have recognised a gender barrier in the acquisition and dissemination of religious scholarship.

Like their male colleagues, females clearly worked hard to contribute into the world of formal religious training. The actual academic training of the best of these women scholars appear to match that of the best male scholars in rigour and thoroughness, a fact that was acknowledged in their own time. This gives the amount of academic recognition that came their way as a result.

Islam raised the status of a girl child by providing her with right to life, right to education, care and support on equal footings with boys. Prophet Muhammad (S.A.W.) equated good treatment of girl child with safety from Hell. He said: "If a daughter is born to a person and he brings her up, gives her good education and trains her in the arts of life, I shall myself stand between him and hellfire" (Muhammad, 1989).

Montgomery Watt, a Christian Islamic scholar attests to the positive change Islam brought to woman's life. He says: "prior to the time Islam began, the conditions of women were terrible - they had no right to own property, were supposed to be the property of the man, and if the man died everything went to his sons". According to Muhammad, however, by, "instituting rights of property ownership, inheritance, education and divorce, gave women certain basic safeguards" (Aysu, 2006). 


\section{Contributions of Women to Civilisation}

Historically, women played an important role in the foundation of many Islamic educational institutions, such as Fatimah al-Fihri's founding of the University of Al Karaouine in 859 C.E. This continued through the Ayyubid dynasty in the 12th and 13th centuries, when 160 mosques and madrasahs were established in Damascus, 26 of which were funded by women through the Waqf (charitable trust or trust law) system. Half of all the royal patrons for these institutions were also women.

In $19^{\text {th }}$ century West Africa, Nana Asma'u, was a leading Islamic scholar, poet, teacher and an exceptionally prolific Muslim female writer who wrote more than 60 works (Boyd, 1989). Female education in the Islamic world was inspired by Muhammad's wives: Khadijah, a successful business woman and Aisha, a renowned hadith scholar and military leader (Muhammad, 1989).

Women are allowed to work in Islam, subject to certain conditions, such that her employment does not cause her to neglect her role as a mother and wife. It has been claimed that, where possible, the Muslim community owes it a responsibilities to organise work for women, so that they can do so in a Muslim cultural atmosphere, where her rights (as set out in the Qur'an) are respected.

In the 12th century, the famous Islamic philosopher and qadi (judge) Ibn Rushd, known to the West as Averroes, claimed that women were equal to men in all respects and possessed equal capacities to shine in peace and in war, citing examples of female warriors among the Arabs, Greeks and Africans to support his case. Besides, nearly one-third of the Parliament of Egypt (which is an example of a Muslim nation) also consists of women (Aysu, 2006).

\section{Modern Debate on the Status of Women in Islam}

Modern development has emboldened women to fight for rights similar to their male counterparts and to denounce any seeming legislation that tends to subjugate their freedom.

In 2006, for instance, Marina Mahathir, the daughter of Malaysia's former Prime Minister, Mahathir Muhammad, published an editorial in the Malaysia Star newspaper to denounce what she termed "a growing form of apartheid" for Malaysia's Muslim women (Aysu, 2006). Her protest was immediately looked into and appropriate adjustment was guaranteed in line with the provisions of the Islamic law.

Islam holds women in high regard. Indeed, Souad Saleh, a female professor at Al-Azhar University in Cairo and a vocal proponent of women's rights in Egypt, recently stated, "Islam is pure and simple, and it holds women in high esteem" (Wikipedia, 2013).

A foremost Mufti in Saudi Arabia, Shaykh' Abdul-' Azeez Ibn' Abdullaah Ibn Baaz, when asked about the woman's role in the propagation of Islam replied thus, "She is like the man, she can enjoin good and forbid evil, since the texts from the Noble Qur'an and the Pure Sunnah prove this, and opinions of the scholars are clear about this (Abu Loghod, 1998). So, she should call on Allah, enjoin goodness and forbid evil in accordance with the manners prescribed in the shari'ah that are required from man.

Prophet Muhammad (S.A.W.) became the first teacher of women, emphasised their education and said: "whoever brings up three daughters or three sisters or two sisters or two daughters and gives them good education, treats them well and gives them out in marriage, for him is paradise" (Muhammad, 1989). Thus, education is the foundation and key of existence. Therefore, Islam does not discriminate against anyone in the search, dissemination and application of knowledge. 
Islam sets in motion a process that would guarantee women's equality with men before Allah and creates general awareness for every female to possess a distinct individuality of her own. It also advocates for the prohibition of preferential treatment of any sort among children to emphasizing special care to girls, laying down rights and responsibilities of partners in marriage and rights to inheritance.

\section{An Exploration of Islamic Perspective to Modernism}

Modernisation projects started in the late Ottoman period and continued in the republican era (Aysu, 2006). It had a great impact on today's social structure. State feminism and the liberal feminist agenda emphasised different aspects of women's status. While state feminism started the emancipation project, the second gave rise to one women's movement and improved women's perceptions of themselves. After the 1980s, and with the rise of the Islamist movement, women who adopted Islamic ideology also became active (Suad, 2007).

The Islamist movement has presented itself as an alternative to the modernisation. Islam, as a religion ,supports the differences between the sexes. In Shari'ah (Islamic Law), women and men are not equal because of their nature. In Islamic tenets, man and woman complete each other. The religion puts more premium on justice over and above equality, while differences do not depend on gender but on sex (Ahmed, 1992). In this world, women and men have different roles based on their sexes, and both have to practise their roles as stated in the Qur'an.

Studies on women in Islam have emphasised the context and settings, since these have great impacts on religion and its effects on the society (Bullough, 2001). Since Islam was a reform that took place after the Jahiliyyah period (Ahmed, 1992), references to this period present women as weak and sick human beings who were treated worse than animals and even might be killed when they were born. Therefore, Islam provides women with some rights and these rights were equal to half of what men had at that time. These laws and rules were shaped by the juncture of Arab societies and women's position within these societies. These rules, however, were applied in exactly the same way to women in other societies.

Citing Turkey as a replica of an Islamic nation as quoted by Aysu (2006), the Presidency of Religious Affairs in Turkey has stated:

In Islam, women have the same basic rights and freedoms as men have; and there is no kind of restriction to their rights and responsibilities. Everyone - whether they are man or woman - has the right to work, to trade, and to have a public job, provided they follow the basic Islamic principles and rulings, and show respect for the general rules of ethics.

They both share religious responsibility in legal matters, and both have basic rights and freedom. However, the social and cultural milieu, and especially the patriarchal family structure in which Islam flourished, were the dominant factors in determining the position of women. This situation is the main reason for various understandings or practices concerning women modernism in Islamic hermeneutics.

One has to take into consideration the social and cultural conditions of the revelation of the Qur'anic verses, their literal meaning, and their aim in understanding and interpreting the Qur'anic verses about women. There is no decree in Islam, which forbids woman from seeking employment whenever there is a necessity for it, especially in positions which fit her nature and in which society needs her most. Examples of these professions are nursing, teaching and medicine. Moreover, there is no restriction on benefiting from woman's exceptional talent in any field. Even for the position of a judge, where there may be a tendency to doubt the woman's fitness for the post due to her more emotional nature. People find early Muslim scholars such as 
Abu-Hanifa and Al-Tabary holding that there is nothing wrong with it. In addition, Islam restored to woman the right of inheritance, after she had been an object for inheritance in some cultures. Her share is completely hers and no one can make any claim on it, including her father and her husband.

Unto men (of the family) belong to a share of that which parents and near kindred leave, and unto women a share of that which parents and near kindred leave, whether it is a little or much - a determinate share (Qur'an).

Any fair investigation into the history of the Islamic civilization and modernisation will surely find a clear evidence of woman's equality with man in what people call today "political rights". This includes right of election as well as nomination to political offices. It also includes woman's right to participate in public affairs. Both in the Qur'an and in Islamic history, people find examples of women who participated in serious discussions. (Qur' an).

During the Caliphate of Umar Ibn al-Khattab (434-644 C.E.), a woman argued with him in the mosque, proved her point, and caused him to declare in the presence of people: "A woman is right and 'Umar is wrong" (Muhammad, 1997).

Female may head any post aside the head of state. This is due to the sensitivity of the post as well as her nature. A prophetic tradition concels thus: "People will not prosper if they let a woman be their leader" (Abdullah, 1986). The leader in this expression refers to an apex post. This limitation, however, has nothing to do with the dignity of woman or with her rights. It is rather related to the natural differences in the biological and psychological make-up of men and women (Abdullah, 1986).

Islam recognises the post of the head of a state as of high tasks. Such a leader leads people in all affairs of a state. He is continuously engaged in the process of decision-making pertaining to the security and well-being of his people. This demanding position, or any similar one, such as the commander of the Army, is generally inconsistent with the physiological and psychological make-up of woman in general. It is a medical fact that during their monthly periods and during their pregnancies, women undergo various physiological and psychological changes. Such changes may occur during an emergency situation, thus affecting her decision, without considering the excessive strain it may produce. Moreover, some decisions require a maximum of rationality and a minimum of emotionality - a requirement which does not coincide with the instinctive nature of women.

Even in modern times, and in the most developed countries, it is rare to find a woman in the position of a head of state. There is a number of women as commanders of the armed services, or even a proportionate number of women are representatives in parliaments (Africa not an exception) or similar bodies. This cannot be ascribed to backwardness of various nations or to any constitutional limitation on women's right to be in such a position as head of state or as a member of the parliament. It is more logical to explain the present situation in terms of natural and indisputable differences between man and woman, a difference which does not imply any supremacy of one over the other. The difference rather implies complementary roles of both sexes in life.

\section{Conclusion}

Islamic hermeneutics on modernism have been analysed. Muslim women are completely permitted to work, and to be highly educated. Islam does not say that women should be used as cleaners or cooks around the home. Rather they should play their roles in running a home and also in the development of the society. 
Women, like men are enjoined to compulsorily seek for knowledge as a means of contributing to improve the society. This is emphasised by a prophetic tradition thus: "Seeking of knowledge is incumbent upon every Muslim (male and female)". A large number of Muslim scholars were women, such as Aishah, wife of the prophet, Amrah Bint Abdur Rahman, Rabiah Al-Adawiyyah and other wives of the prophet. Other women worthy of mention are Jawdaniyyah, who had the best knowledge of chain of transmitters of traditions of the Prophet and who had the best memory in her time; Ajeebah Al-Baqdariyyah, who was the only one in the world in her time to narrate certain Ahadith (Abdullah, 2006). Nearer home, Asma'u Bint Fodio, daughter of renowned scholar and reformer Shaykh 'Uthman Bn Fudi was as great a scholar as any of the contemporary students of her great father as evidenced by the many books, poems, pamphlets and treatise on a wide range of subjects she left behind.

The scope of education in Islam is wide and all encompassing. Its only criteria are that it should move within the frame work of Islam and its concepts and utilise the two main sources of knowledge prescribed by it. Islam does not discriminate against any person-male or female with regards to seeking, disseminating and applying knowledge.

Education is considered as a tool to modernism for female Muslims. This is so, because without education, girls are denied the opportunity to develop their full potentials and to play a productive and equal role in their families, their societies, their countries and the world at large. Woman is accountable for her deeds just as the men are; and she has to seek for knowledge in order to fulfil her needs in both this world and the hereafter. Islam equips Women with knowledge as their male counterpart in order that both may reform the society and contribute to its advancement in a world that is moving fast. This is what is now referred to as modernism.

\section{Recommendations}

From the analysis expressed above, the following recommendations are put forward:

Muslim women should be highly educated and enlightened citizens of the world. Travelling widely and enriching their knowledge and intellect. Only then, can they reap the benefits of education as a need for modernisation. Nevertheless, with adequate knowledge, preparation and planning, the goal will be attained.

Muslim women should be heedful of the teachings of the Qur'an, following the path of Prophet Muhammad (SAW) as regards learning and application of it to the advancement of the society and be steadfast. Only then, can they be more useful.

They should as well know that not much is achieved by one person or group. Therefore, they should come together and work in unison in order to achieve results (Qur'an 28:56). A knowledgeable Muslim woman is like a building that has a very firm foundation which cannot be compared to the weak one.

\section{References}

Abdullah, O. N. (1986). Encyclopedia of Seerah. London: Seerah Foundation.

Abu-Lughod, Lila. (1998). Feminist Longings and Postcolonial Conditions. (pp.3-31). Remaking Women; Feminism and Modernity in Middle East Edited by Lila Abu-Lughod. Princeton.

Ahmed, Leila. (1992). Women and Gender in Islam: Historical roots of a modern Debate. London: Yale University Press.

Al-Hilali, M.T., \& Khan, M. M. (1983). Translation of the Noble Qur'an in the English language. King Fahd complex, Madinah, K.S.A.

Alya, B. (1982). Women and Social Change in the Muslim Arab World. Women in Islam. Pergamon: Pergamon Press.

Aysu, G. G. (2006). Women in the 20th century: Modernity, feminism, and Islam in turkey. M. A. Dissertation, Faculty of the Graduate School, the University of Texas, Arlington. 
Boyd, Jean. (1989). The Caliph's Sister. Nana Asma'u, 1793-1865: Teacher, Poet and Islamic Leader. London: Frank Cass. Bullough, Vern L. (2001). Islam, Encyclopedia of Birth Control.

Esposito, J. (2011). What Everyone Needs to Know About Islam. New York: Oxford University Press.

Friedmann, Y. (2003). Tolerance and Coercion in Islam: Interfaith Relations in the Muslim Tradition. U.K.: Cambridge University Press.

Jamal A. B. (1980). The Status of Woman in Islam. Journal, Al-lttihad, Vol. 8, No. 2.

Katja, W. (2011). The example of Nana Asma’u. Germany: Gutenberg University, Mainz.

Leila, A. (1992). Women and Gender in Islam: Historical roots of a modern debate. Yale: University Press.

Levy, R. (1969). The Social Structure of Islam. U.K.: Cambridge University Press.

Moghadam, V. M. (1992). Patriarchy and the Politics of Gender in Modernizing Societies. Iran: International Sociology.

Muhibuddin, K. (1994). Woman between Islam and Western Society. India: New Delhi.

Muhammad, A. A. (1990). Management and Administration in Islam. Saudi Arabia: King Fahd University of Petroleum.

Muhammad, M. K. (1989). Sahih al-Muslim, K.S.A. Darussalam.

Muhammad, B. I. (1997). al fiqh ul wadih. 2 Cairo: darul manar.

Muhammad, M. K. (1990). The Noble Qur'an. Saudi: Darus Salam Publication.

Roded, R. (1994). Women in Islamic biographical collections:From Ibn Sa d to Who's who. London: Lynne Rienner Publishers. Santa-Barbara, Esposito, J. (2003). The Oxford Dictionary of Islam. Oxford: Oxford University Press.

Suad, J. (2007). Encyclopedia of Women and Islamic Cultures. Leiden: Brill.

Sally,W. (2001). Oxford Advanced Learner's Dictionary. Oxford: Oxford University Press.

Sirman, N. (1989). Feminism in Turkey: A Short History. New Perspectives on Turkey, 3(1), 1-34.

Yvonne H., \& John E. (1998). Islam, Gender, and Social Change. U.S.: Oxford University Press. 